\title{
Search for novel antifungal compounds among arylamides of 3-[3,5-dioxy-1,2,4,5-tetrahydro- 1,2,4-triazinyl-6]-propionic acid
}

\author{
I. V. Alexeeva, L. G. Palchikovska, V .G. Kostina, M. O. Platonov, L. V. Pavlenko, N.
}

\author{
A. Lysenko, A .D. Shved
}

Institute of molecular biology and genetics NAS of Ukraine

Academicain Zabolotnog str., 150, Kyiv, 03680 Ukraine

shved_@imbg.org.ua

\begin{abstract}
Design and synthesis of a set of 3,5-dioxy-1,2,4-triazinyl-6-propionic acid (TPA) arylamides were developed in order to search for new compounds with fungistatic properties on the basis of azapyrimidine derivatives. Carboxamides capable to block transcription were revealed among obtained compounds using T7 RNA-pol model test-system in vitro, and the only derivatives containing halogene-substituent in pharmacophore part showed the inhibitory properties. The model of virtual triple non-productive complex at polymerase catalytic site (inhibitor-enzyme-DNA template) was proposed, illustrating a possible mechanism of inhibitory action of such compounds on RNA synthesis. Preliminary screening of new triazine derivatives revealed their inhibitory action against some kinds of fungi and bacteria.
\end{abstract}

Keywords: 1,2,4-triazine derivatives, synthesis, suppression of transcription, T7 RNA-pol, antifungal activity.

Introduction. A significant number of antimicotics of different classes, including polyene antibiotics, derivatives of nitrogen-containing heterocycles, and analogues of nucleotide bases etc., are known up to date [1-4]. However, the formation of drug resistance in numerous mycosis- and mycotoxicosis-causing agents motivates the scientists to constant search for new efficient fungicides, which is current and important task of mycotoxicology.

(C) I. V. ALeXeEVA, L. G. PALChiKovska, V .G. Kostina, M. O. PLATONOV,

L. V. PAVLENKO, N. A. LYSENKO, A .D. SHVED, 2007
Earlier we have synthesized and analyzed antimicrobial effect of several 6-azauracil derivatives (1,2,4-triazin-3,5-(2H, 4H)-dione), which contained carboxamide fragment in the structure of C5-substituent. Azauracilyl-5-propionic acid derivatives were revealed to be the most effective (according to the degree) antimicrobial agents among three analyzed series of compounds $[5,6]$.

Thus, we continue to construct new biologically active compounds on the basis of polyfunctional base molecule of TPA, which allows synthesizing different types of structures. 


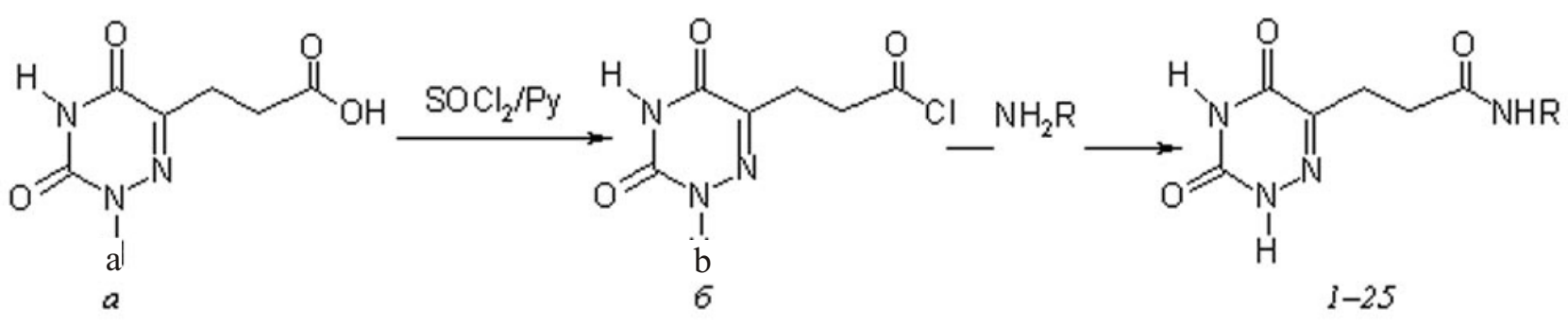

where $\mathrm{R}$ - mono or di-substituted aromatic cycle

Fig.1 Scheme of synthesis of phenylamides (1-25) of 3,5-dioxy-triazinyl-6-propionic acid $(a)$ on the basis of their acid chloride (b)

It has to be mentioned that triazine compounds are generally not toxic (it has been established by experiments on laboratory animals). There are some data revealing rapid destruction of triazine compounds in the natural environment, they are also not accumulated in soil and water-storage reservoirs [7]. The presence of the mentioned features is expected from new generation of synthesized compounds - triazine derivatives.

Thus, synthesis of new compounds, testing on enzymatic and cell screening systems, and determination of correlation between physical-chemical parameters and biological activity of triazine derivatives will allow clarifying some features of mechanism of their effect and setting the direction for further design of compounds with theoretically predicted biological response.

Materials and Methods. Reagents and solvents, manufactured by Chemlaborreactive (Ukraine) and MBI Fermentas (Lithuania), were used in this work. Original compound 3,5-dioxo-1,2,4-triazinyl-6-propionic acid and its amides were synthesized by methods, described in [8]. The course of reaction and the purity of synthesized compounds were registered using the method of thin-layer chromatography (TLC) on Silicagel $60 \mathrm{~F}_{254}$ plates (Merck, Germany) in chloroform:methanol system (4:1 and 9:1). Column chromatography was carried out using Silicagel 60 (230-400 mesh) (Merck).

The melting point of compounds was determined using Boetius device (Germany). ${ }^{1} \mathrm{H}-\mathrm{NMR}$ spectra of synthesised compounds were recorded at $400 \mathrm{MHz}$ us-

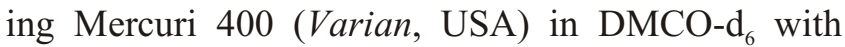

tetramethylsilane as a reference. Infrared spectra of compounds, pressed into $\mathrm{KBr}$ (tablets) pellets, were registered using Specord-M 80 spectrometer (Germany).

Quantum-chemical calculations and molecular design. Semi-empirical quantum-chemical calculations were performed by PM3 method, non-empirical ones were performed by $a b$ initio method at the level of B3LIP/6-31 (d, p)//HF/6-31G(d, p). To design the complex of target ligands we used Gamess software pack [9].

General method of obtaining arylamides of 3,5-dioxy-triazinyl-6-propionic acid (1-25). The procedure used to prepare a set of amide derivatives of TPA was as follows: thionyl chloride $(1.4 \mathrm{mmol})$ and freshly dried pyridine $(1.4 \mathrm{mmol})$ were added to the suspension of TPA $(1.0 \mathrm{mmol})$ in $10 \mathrm{ml}$ of dry dioxane at stirring. During 15-20 minutes the crystalline structure of acid was transformed to oil-like product. After $\sim 10$ min the resulting mass was combined with excess (2-2.5 mmol) of the appropriate amine and stirred for another $12 \mathrm{~h}$. The following day the solvent was removed under vacuum and water was added to the solid residue. The precipitate formed was collected by filtration, washed with water and dried. The crude product was crystallized from corresponding solvents or mixture of solvents yielding the analytically pure compound.

Method of biotesting using model transcription system was presented in the previous publication [10]. The following products of Fermentas were used: linearised matrix pTZ19R, four nucleoside triphosphates (ATP, 
Table

Physical-chemical characteristics of $N$-phenylamide of triazinyl-6-propanecarbonic acid

\begin{tabular}{c|c|c|c}
\hline Compound & $\mathrm{R}$ & M.p., ${ }^{\circ} \mathrm{C}$ (solvent) & NMP-spectrum, $\delta$, p.p.m.., DMSO-d 6 \\
\hline 1 & 2 & 3 & 4 \\
\hline
\end{tabular}

1.

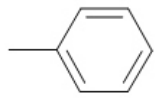

2.

$\mathrm{H}_{3} \mathrm{C}$

3

4.

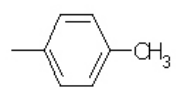

5.

6

7.

8.

9.

10.

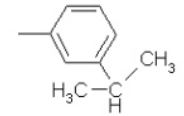<smiles>Cc1ccc(C)c(C)c1</smiles>

.<smiles>Cc1cc(C)cc(C)c1</smiles>

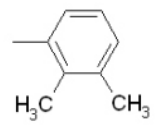

$=C^{\mathrm{CF}}$

$\mathrm{H}_{3} \mathrm{C}-\mathrm{O}$

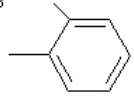

11.

12.

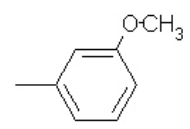

13.

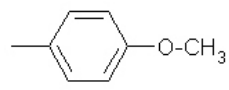

14.

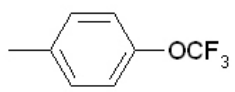

15.

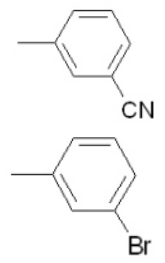

242-244

(water-ethanol)

218-220

(water-ethanol)

227-230

(water-ethanol)

270-272

(water-ethanol)

174-76

(water-ethanol)

254-256

(water-ethanol)

218-220

(water-ethanol)

237-239

(water-ethanol)

214-215

(water-ethanol)

225-227

(water-ethanol)

216-218

(water-ethanol)

259-261

(water-ethanol)

259-263

(water-ethanol)

234-236

(water-ethanol)

247-249

(water-ethanol)
2.60 t $\left(2 \mathrm{H}, \mathrm{CH}_{2}\right) ; 2.70$ t $\left(2 \mathrm{H}, \mathrm{CH}_{2}\right) ; 7.20$ t $(1 \mathrm{H}, \mathrm{Ph}) ; 7.28 \mathrm{t}(2 \mathrm{H}, \mathrm{Ph})$; $7.58 \mathrm{~d}(2 \mathrm{H}, \mathrm{Ph}) ; 10.00 \mathrm{~s}(1 \mathrm{H}, \mathrm{NH}) ; 12.00 \mathrm{~s}(2 \mathrm{H}, \mathrm{N} 2 \mathrm{H}, \mathrm{N} 4 \mathrm{H})$

$2.15 \mathrm{~s}\left(3 \mathrm{H}, \mathrm{CH}_{3}\right) ; 2.85-2.72 \mathrm{~d}\left(4 \mathrm{H}, \mathrm{CH}_{2} \mathrm{CH}_{2}\right) ; 7.15 \mathrm{~m}(3 \mathrm{H}, \mathrm{Ph}) ; 7.45 \mathrm{~d}$ $(1 \mathrm{H}, \mathrm{Ph}) ; 9.32 \mathrm{~s}(1 \mathrm{H}, \mathrm{NH}) ; 11.92 \mathrm{~s}(1 \mathrm{H}, \mathrm{NH}) ; 12.09 \mathrm{~s}(1 \mathrm{H}, \mathrm{NH})$

$2.29 \mathrm{~s}\left(3 \mathrm{H}, \mathrm{CH}_{3}\right) ; 2.61 \mathrm{~d} ; 2.77 \mathrm{~d}\left(4 \mathrm{H}, \mathrm{CH}_{2} \mathrm{CH}_{2}\right) ; 6.78 \mathrm{~d}(1 \mathrm{H}, \mathrm{Ph}) ; 7.10 \mathrm{t}$ $(1 \mathrm{H}, \mathrm{Ph}) ; 7.32 \mathrm{~d}(1 \mathrm{H}, \mathrm{Ph}) ; 7.40 \mathrm{~s}(1 \mathrm{H}, \mathrm{Ph}) ; 9.75 \mathrm{~s}(1 \mathrm{H}, \mathrm{NH}) ; 11.85 \mathrm{~s}$ $(1 \mathrm{H}, \mathrm{NH}) ; 12.00 \mathrm{~s}(1 \mathrm{H}, \mathrm{NH})$

$2.21 \mathrm{~s}\left(3 \mathrm{H}, \mathrm{CH}_{3}\right) ; 2.58 \mathrm{t}\left(2 \mathrm{H}, \mathrm{CH}_{2}\right) ; 2.72 \mathrm{t}\left(2 \mathrm{H}, \mathrm{CH}_{2}\right) ; 7.05 \mathrm{~d}(2 \mathrm{H}, \mathrm{Ph}) ;$ $7.42 \mathrm{~d}(2 \mathrm{H}, \mathrm{Ph}) ; 9.86 \mathrm{~s}(1 \mathrm{H}, \mathrm{NH}) ; 11.91 \mathrm{~s}(1 \mathrm{H}, \mathrm{NH}) ; 12.11 \mathrm{~s}(1 \mathrm{H}, \mathrm{NH})$

$1.21 \mathrm{t}\left(6 \mathrm{H}, 2 \mathrm{CH}_{3}\right) ; 2.61 \mathrm{~m}\left(2 \mathrm{H}, \mathrm{CH}_{2}\right) ; 2.86 \mathrm{t}\left(2 \mathrm{H}, \mathrm{CH}_{2}\right) ; 6.83 \mathrm{~d}(1 \mathrm{H}$, $\mathrm{Ph}) ; 7.11 \mathrm{t}(1 \mathrm{H}, \mathrm{Ph}) ; 7.36 \mathrm{~d}(1 \mathrm{H}, \mathrm{Ph}) ; 7.45 \mathrm{~s}(1 \mathrm{H}, \mathrm{Ph}) ; 9.75 \mathrm{~s}(1 \mathrm{H}, \mathrm{NH})$; $11.83 \mathrm{~s}(1 \mathrm{H}, \mathrm{NH}) ; 11.99 \mathrm{~s}(1 \mathrm{H}, \mathrm{NH})$

$2.13 \mathrm{~s}\left(3 \mathrm{H}, \mathrm{CH}_{3}\right) ; 2.27 \mathrm{~s}\left(3 \mathrm{H}, \mathrm{CH}_{3}\right) ; 2.62 \mathrm{~m}\left(2 \mathrm{H}, \mathrm{CH}_{2}\right) ; 6.83 \mathrm{~d}(1 \mathrm{H}, \mathrm{Ph})$; $7.01 \mathrm{~d}(1 \mathrm{P}, \mathrm{Ph}) ; 7.19 \mathrm{~s}(1 \mathrm{H}, \mathrm{Ph}) ; 9.10 \mathrm{~s}(1 \mathrm{H}, \mathrm{NH}) ; 11.90 \mathrm{~s}(1 \mathrm{H}, \mathrm{NH})$; $12.14 \mathrm{~s}(1 \mathrm{H}, \mathrm{NH})$

$2.25 \mathrm{~s}\left(6 \mathrm{H}, 2 \mathrm{CH}_{3}\right) ; 2.58 \mathrm{t}\left(2 \mathrm{H}, \mathrm{CH}_{2}\right) ; 2.75 \mathrm{t}\left(2 \mathrm{H}, \mathrm{CH}_{2}\right) ; 6.59 \mathrm{~s}(1 \mathrm{H}, \mathrm{Ph}) ;$ 7.16 t $(2 \mathrm{H}, \mathrm{Ph}) ; 9.63 \mathrm{~s}(1 \mathrm{H}, \mathrm{NH}) ; 11.82 \mathrm{~s}(1 \mathrm{H}, \mathrm{NH}) ; 11.98 \mathrm{~s}(1 \mathrm{H}, \mathrm{NH})$

$2.05 \mathrm{~s}\left(3 \mathrm{H}, \mathrm{CH}_{3}\right) ; 2.26 \mathrm{~s}\left(3 \mathrm{H}, \mathrm{CH}_{3}\right) ; 2.61 \mathrm{t}\left(2 \mathrm{H}, \mathrm{CH}_{2}\right) ; 2.77 \mathrm{t}\left(2 \mathrm{H}, \mathrm{CH}_{2}\right) ;$ $6.96 \mathrm{~m}(2 \mathrm{H}, \mathrm{Ph}) ; 7.09 \mathrm{~d}(1 \mathrm{H}, \mathrm{Ph}) ; 9.26 \mathrm{~s}(1 \mathrm{H}, \mathrm{NH}) ; 11.84 \mathrm{~s}(1 \mathrm{H}, \mathrm{NH})$; $12.02 \mathrm{~s}(1 \mathrm{H}, \mathrm{NH})$

$2.70 \mathrm{~m}\left(4 \mathrm{H}, \mathrm{CH}_{2} \mathrm{CH}_{2}\right) ; 7.38 \mathrm{~d}(1 \mathrm{H}, \mathrm{Ph}) ; 7.53 \mathrm{t}(1 \mathrm{H}, \mathrm{Ph}) ; 7.74 \mathrm{~d}(1 \mathrm{H}, \mathrm{Ph}) ;$ $10.35 \mathrm{~s}(1 \mathrm{H}, \mathrm{NH}) ; 12.00 \mathrm{~s}(2 \mathrm{H}, \mathrm{N} 2 \mathrm{H}, \mathrm{N} 4 \mathrm{H})$

$2.74 \mathrm{dd}\left(4 \mathrm{H}, \mathrm{CH}_{2} \mathrm{CH}_{2}\right) ; 3.85 \mathrm{~s}\left(3 \mathrm{H}, \mathrm{OCH}_{3}\right), 6.85 \mathrm{t}(1 \mathrm{H}, \mathrm{Ph}) ; 6.93 \mathrm{~d}(1 \mathrm{H}$, $\mathrm{Ph}) ; 7.00 \mathrm{t}(1 \mathrm{H}, \mathrm{Ph}) ; 7.99 \mathrm{~d}(1 \mathrm{H}, \mathrm{Ph}) ; 8.89 \mathrm{~s}(1 \mathrm{H}, \mathrm{NH}) ; 11.82 \mathrm{~s}(1 \mathrm{H}$, $\mathrm{NH}) ; 11.96 \mathrm{~s}(1 \mathrm{H}, \mathrm{NH})$

2.60-271 m (4H, $\left.\mathrm{CH}_{2} \mathrm{CH}_{2}\right) ; 3.68 \mathrm{~s}\left(\mathrm{OCH}_{3}\right) ; 6.61 \mathrm{~d}(1 \mathrm{H}, \mathrm{Ph}) ; 7.25$-7.30 $\mathrm{m}(2 \mathrm{H}, \mathrm{Ph}) ; 9.95 \mathrm{t}(1 \mathrm{H}, \mathrm{NH}) ; 12,01 \mathrm{~m}(2 \mathrm{H}, \mathrm{N} 2 \mathrm{H}, \mathrm{N} 4 \mathrm{H})$

$2.58 \mathrm{~m}\left(2 \mathrm{H}, \mathrm{CH}_{2}\right) ; 2.74 \mathrm{~m}\left(2 \mathrm{H}, \mathrm{CH}_{2}\right) ; 3.73 \mathrm{~s}\left(3 \mathrm{H}, \mathrm{OCH}_{3}\right) ; 6.78 \mathrm{~d}(2 \mathrm{H}$, $\mathrm{Ph}) ; 7.46 \mathrm{~d}(2 \mathrm{H}, \mathrm{Ph}) ; 9.71 \mathrm{~s}(1 \mathrm{H}, \mathrm{NH}) ; 11.84 \mathrm{~s}(1 \mathrm{H}, \mathrm{NH}) ; 12.00 \mathrm{~s}(1 \mathrm{H}$, $\mathrm{NH})$

$2.63 \mathrm{~m}\left(2 \mathrm{H}, \mathrm{CH}_{2}\right) ; 2.77 \mathrm{~m}\left(2 \mathrm{H}, \mathrm{CH}_{2}\right) ; 7.16 \mathrm{~d}(2 \mathrm{H}, \mathrm{Ph}) ; 7.67 \mathrm{~d}(2 \mathrm{H}$, $\mathrm{Ph}) ; 10.05 \mathrm{~s}(1 \mathrm{H}, \mathrm{NH}) ; 11.85 \mathrm{~s}(1 \mathrm{H}, \mathrm{NH}) ; 12.00 \mathrm{~s}(1 \mathrm{H}, \mathrm{NH})$

$2.66 \mathrm{t}\left(2 \mathrm{H}, \mathrm{CH}_{2}\right) ; 2.71 \mathrm{t}\left(2 \mathrm{H}, \mathrm{CH}_{2}\right) ; 7.42 \mathrm{~m}(2 \mathrm{H}, \mathrm{Ph}) ; 7.79 \mathrm{~d}(1 \mathrm{H}, \mathrm{Ph})$ $8.05 \mathrm{~s}(1 \mathrm{H}, \mathrm{Ph}) ; 10.21 \mathrm{~s}(1 \mathrm{H}, \mathrm{NH}) ; 11.84 \mathrm{~s}(1 \mathrm{H}, \mathrm{NH}) ; 12.01 \mathrm{~s}(1 \mathrm{H}$, $\mathrm{NH})$

$2.63 \mathrm{t}\left(2 \mathrm{H}, \mathrm{CH}_{2}\right) ; 2.78 \mathrm{t}\left(2 \mathrm{H}, \mathrm{CH}_{2}\right) ; 7.16 \mathrm{~m}(2 \mathrm{H}, \mathrm{Ph}) ; 7.45 \mathrm{~d}(1 \mathrm{H}, \mathrm{Ph})$; $7.91 \mathrm{~s}(1 \mathrm{H}, \mathrm{Ph}) ; 10.03 \mathrm{~s}(1 \mathrm{H}, \mathrm{NH}) ; 11.6 \mathrm{~s}(1 \mathrm{H}, \mathrm{NH}) ; 12.1 \mathrm{~s}(1 \mathrm{H}, \mathrm{NH})$ 


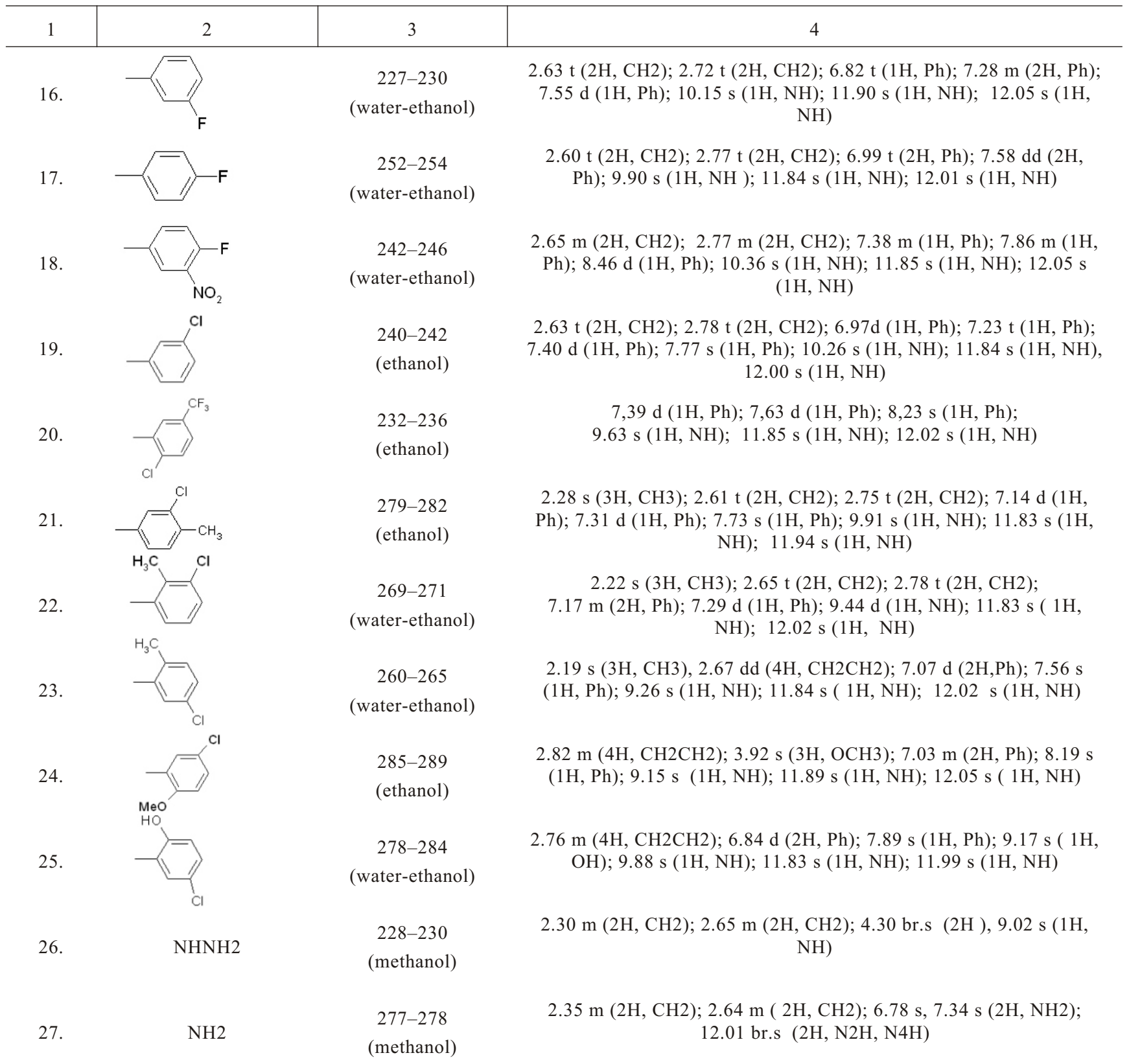

NB: $\mathrm{s}$ - singlet, $\mathrm{t}$ - triplet, $\mathrm{d}-$ doublet, $\mathrm{m}$-multiplet

GTP, CTP, TTP), RNAse inhibitor, buffer (tris- $\mathrm{HCl}$, $\mathrm{pH} 7.5, \mathrm{MgCl}_{2}$, spermidin, MDTT), T7 RNA polymerase.

Results and Discussion. Figure 1 presents the scheme, in accordance to which library of carboxamides with substituted phenyl ring was synthesized (compound 1-25).

Synthesis of derivatives was performed using the simplified variant of acylation of low-active aryl and cyclic amines, i.e. acid chloride (Fig.1, b) was con- 


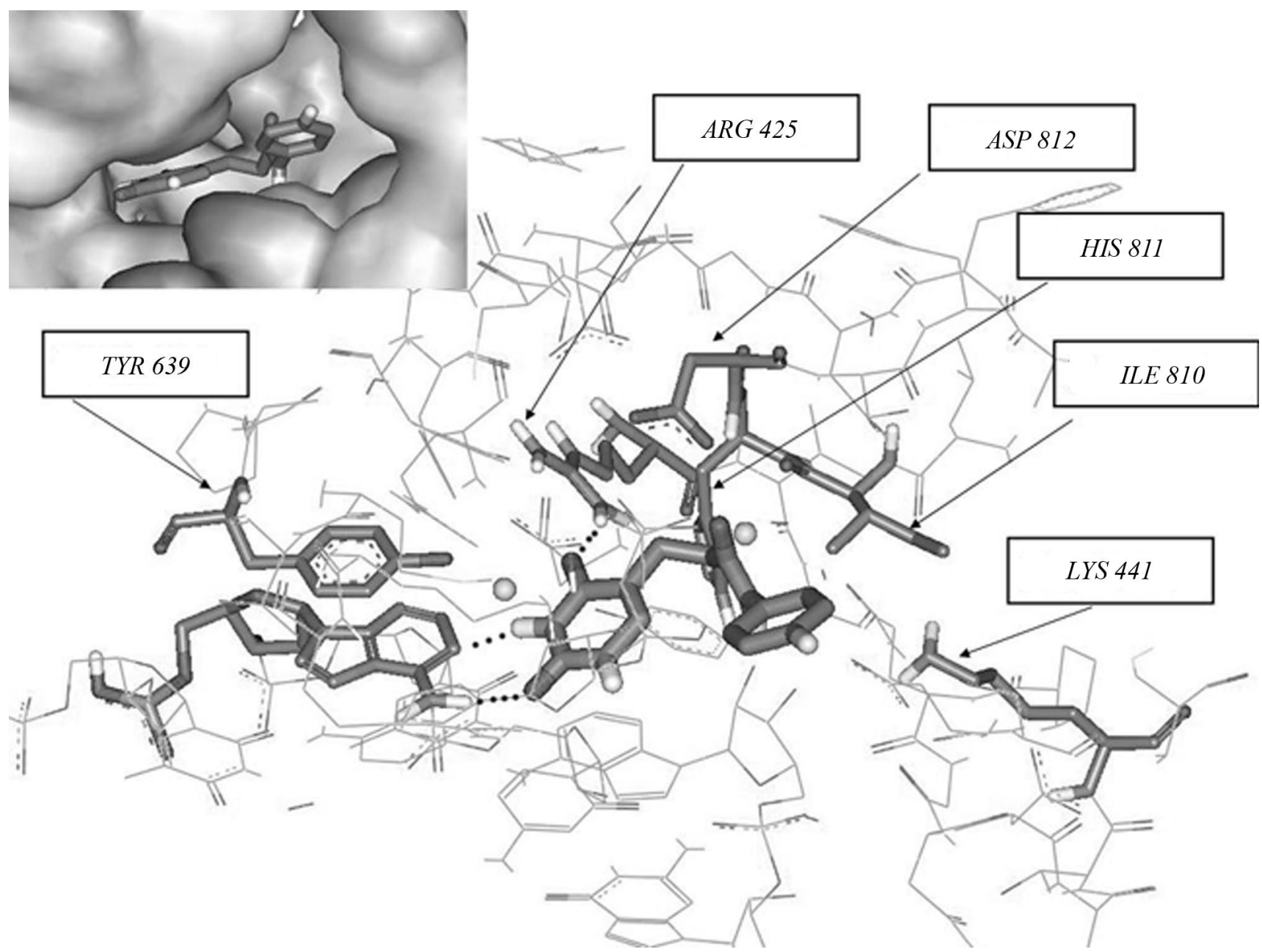

Fig.2 Spatial location of structure of carboxamide 17 in the region of catalytic site T7 of RNA-polymerase; hydrogen bonds, forming triple complex, are marked by dotted line
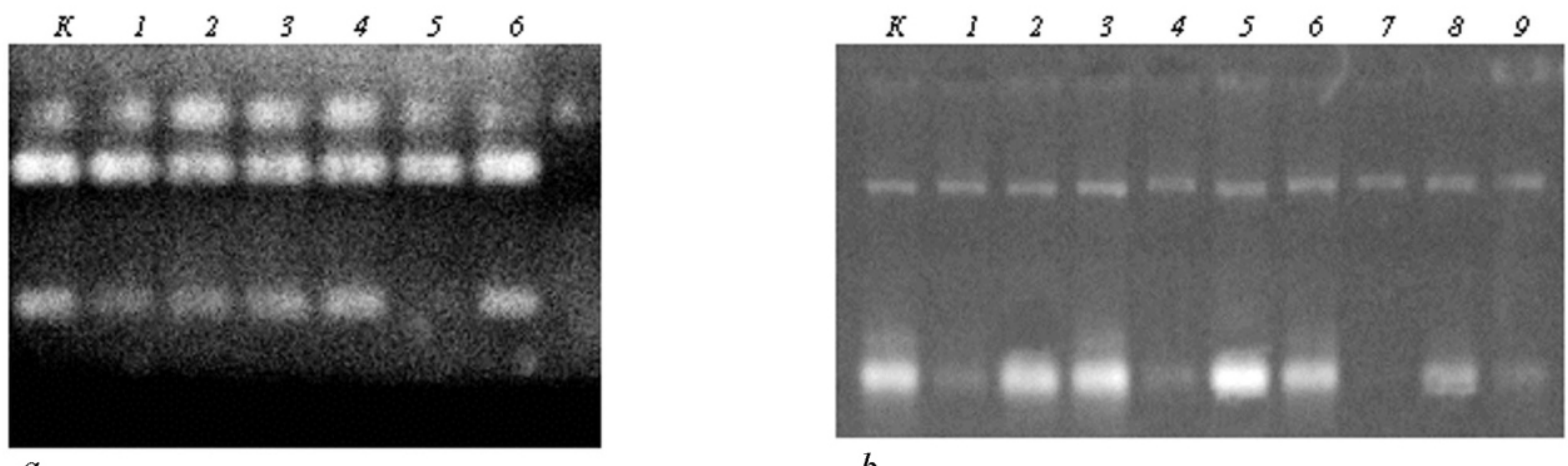

$b$

Fig.3 Electrophoregram of in vitro transcription products (standard reaction) in the presence of phenylamides: $a$ - concentration of test-agents is $50 \mu \mathrm{g} / \mathrm{ml} ; K$ - control; $1-4$ - compounds $1,2,3,4$, respectively; 5 - compound 9; 6 - compound 6 ; $b$ - concentration of test-agents $10 ; 1.0$ and $0.1 \mu \mathrm{g} / \mathrm{ml} ; K$ - control; $1-3$ - compound $19 ; 4,5,6$-compound $17,7-9$ - compound 15 in the mentioned above concentrations 
densed in situ with corresponding aniline or toluidine derivatives.

Reaction was performed in low-polar solvent at the condition of equivalent correlation of thionyl chloride, pyridine and amine surplus. This approach allows obtaining even steric-wise complicated phenylamides of TPA (5-8, 18, 20-25).

Physical-chemical characteristics of obtained compounds are presented in Table.

Analysis of NMR spectra revealed amidic protons of compounds to experience significant influence from aryl fragment, depending on the signal shift in amidic proton according to unsubstituted amide TPA (27) is 2-3 p.p.m. (compounds 8-11).

IR spectra of crystal samples of monosubstituted phenylamides confirm oxo-structure of triazine ring. Thus, in the region of valence vibration of multiple bounds of investigated compounds there are intensive bands of carbonyls $\left(v_{\mathrm{C}=\mathrm{O}}\right)$ of $\beta$-dilactamic fragments of heterocycle, which crosses with $v_{\mathrm{C}=\mathrm{O}}$ of side carboxamide group (1730-1710, 1690-1660 $\left.\mathrm{cm}^{-1}\right)$. There is also intensive band of valence vibration of $\mathrm{C}=\mathrm{C}$ band (app. $1540 \mathrm{~cm}^{-1}$ ), specific for phenyl ring, and less intensive band of $v_{\mathrm{C}=\mathrm{N}}$ of triazine ring $\left(1600-1612 \mathrm{~cm}^{-1}\right)$. The position of bands of valence vibration $\mathrm{C}-\mathrm{H}_{\text {alkyl }}$ of the bond of methylene chain $(\Delta \mathrm{v}=$ $20-30 \mathrm{~cm}^{-1}$ ) changes significantly. Deformation $(\delta)$ vibration of $\mathrm{C}-\mathrm{H}_{\text {arom }}\left(1060-1020 \mathrm{~cm}^{-1}\right)$ are influenced by the lateral substitutes of carboxamide moiety electronic effects. In the case of the monosubstituted phenyl ring the characteristic $\delta$ band is determined in the region of $760-750 \mathrm{~cm}^{-1}$.

Analogues of natural pyrimidine baes are known to influence indirectly biosynthesis of nucleic acids of bacteria and viruses. Thus, antifungal activity of 5-fluorinecytosine is connected to its interfering into metabolism of pyrimidine bases, inclusion into RNA and DNA, and consequently, to the disorders in protein biosynthesis of fungi cells [4]. Triazine bioisosters of pyrimidines - 5- and 6-aza-analogues of uracil and cytosine - are also the substrates of de novo biosynthesis of pyrimidines, capable of incorporating into biopolymers and influencing negatively synthetic and post-synthetic processes of nucleic acids [11].

The other type of pyrimidines - 6-arylamine-(hydrazine)-derivatives - is capable of inhibit- ing functional activity of bacterial or viral DNA-, RNA-polymerases and reverse transcriptases both in vitro and in vivo $[12,13]$.

To evaluate potential capabilities of new compounds we used transcriptional complex of DNA-dependent RNA-polymerase T7 phage as a virtual target and experimental model system. The capability to form $\mathrm{H}$-bonds in the complex of enzyme-ligand-DNA-template, when ligand and target components are in fixed or dynamic states, was analyzed using virtual model of T7 RNA-polymerase. Fig.2 presents the scheme of such triple complex with phenylamide 17. Triazine heterocycle interacts with the environment using three bonds, i.e. hydrogen bonds with purine base of DNA-template and the bond with arginine enzyme, linker chain of carboxamide is bound to another base of DNA template, while phenyl fragment is bound to hydrophobic cavity of protein environment. Taking into account the length of hydrogen bonds (0.19-0.22 nm) and structural complementarity of partners, it is possible to suppose phenylamide 17 to be capable of stabilizing new complex and providing considerable inhibition of the process of RNA synthesis.

Testing of a number of compounds using model enzymatic system of transcription using DNA-dependent T7 RNA-polymerase revealed productivity of synthesis of RNA-transcripts to depend significantly on the nature and position of phenylamide fragment of carboxamide. Meta- and para-halogen containing phenylamides (compounds 9, 15, 17, 19), which inhibited total RNA synthesis in the concentration of 10 $\mu \mathrm{g} / \mathrm{ml}$ completely (Fig.3) were found to be efficient inhibitors of the transcription process.

Fungistatic activity of azapyrimidine line was studied in the representatives of different groups of micromycets and museum and clinical strains of Candida spp. (results will be published elsewhere).

Preparations were shown to be specific for wide range of antimycotic activity - some preparations were shown to be selectively active to toxigenic strains of Aspergillus fumigatus Fres. Notable is their capability to inhibit the growth of five types of Fusarium genus, fusariose agents in plants and animals.

Four new compounds, specific for selective spectrum of antibiotic activity regarding yeast-like fungi of 
Candida genus, including Candida albicans, were revealed among all investigated compounds.

\section{Conclusions.}

1. 100

derivatives

3,5-dioxy-1,2,4-triazinyl-6-propionic acid, including 25 phenylamides, were synthesized. The structures of these compounds were defined and spectral and physical-chemical properties (IR, NMR spectra) were revealed.

2. Primary testing of selected number of TPA phenylamides in cell free system of transcription using DNA-dependent T7 RNA-polymerase revealed some compounds with haloid substitutes in pharmacophoric fragment of carboxamide to inhibit transcription.

3. The model of catalytic T7 RNA-polymerase was used to show for the first time that inhibition of transcription of TPA carboxamides takes place via the formation of non-productive triple complex, i.e. RNA-polymerase-inhibitor-DNA-template.

4. Compounds, specific for the selective spectrum of antibiotic activity of Candida fungal genus, were revealed during the investigation of amides on cell cultures of fungi.

The work was performed within the framework of programme Novel Medical and Biological Problems and Human Environment of National Academy of Sciences of Ukraine.

И. В. Алексеева, Л. И. Пальчиковская, В. А. Костина, М. О. Платонов, Л. В. Павленко, Н. А. Лысенко, А. Д. Швед

Поиск новых соединений с антифунгальной активностью в ряду ариламидов 1,2,4-триазинил-6-пропанкарбоновой кислоты

\section{Резюме}

Для поиска новых соединений с антифунгальным действием на основе производных азапиримидинов осуществлены дизайн и синтез серии ариламидов 1,2,4-триазинил-6-пропанкарбоновой кислоты. Тестирование іп vitro полученных карбоксамидов на модельной системе транскрипиии с использованием ДНК-зависимой 77 РНК-полимеразы показало, что ингибиторное действие характерно для соединений, имеющих галоидзаместители в фармакофорном фрагменте. Смоделировано образование тройного непродуктивного комплекса (ДНК-матрииа-ингибитор-фермент) в участке каталитического сайта полимерази, иллюстрирующего возможный способ угнетения синтеза РНК подобными соединениями. Получены позитивные результаты по биологической активности новых производных триазина в отнотении некоторых видов грибов $и$ бактерий.

Ключевые слова: производные 1,2,4-триазина, ингибирование транскрипщии, Т7 РНК-полимераза, антифунгальная активность

\section{REFERENCES}

1. Boucher H. W., Groll A. H., Chiou C. C., Walsh T. J. Newer systemic antifungal agents: pharmacokinetics, safety and efficacy // Drugs.-2004.-64.-P. 1997-2020.

2. Kauffman C. A. New antifungal agents // Semin. Respir. Grit. Care Med.-2004.-25.-P. 233-239.

3. Nagamatsu T., Yamasaki H., Hirota T., Yamato M., Kido Y., Shibata M., Yoneda F. Synthesis of 3-substituted-1-methyl-6-phenylpyrimido[5,4-e]-1,2,4-triazino-5,7-(1H, 6H)diones (6-phenyl analogs of toxoflavin) and their 4-oxides, and evaluation of antimicrobial activity of toxoflavins and their analogs // Chem. Pharm. Bull. (Tokyo).-1993.-41.P. 362-368.

4. Ghannoum M. A., Rice L. B. Antifungal agents: Mode of action, mechanisms of resistance and correlation of these mechanisms with bacterial resistance // Clin. Microbiol. Revs.-1999.-12.-P. 501-517.

5. Алексеева И. В., Пальчиковская Л. И., Харченко С. Н., Башта Е. В., Платонов М. О., Костина В. Г., Усенко Л. C., Лысенко Н. А., Малько В. А. Новые производные 6-азаурацила-амиды $а с$-триазинкарбоновых кислот: синтез и их антимикробная активность // Біополімери і клітина.2002.-7, № 3.-С. 237-242.

6. Башта О. В., Платонов М. О. Фунгістатична активність сполук азапіримідинового ряду по відношенню до мікрофлори колосу озимої пшениці // Бюл. Ін-ту с.-г. мікробіології (ІСГМ).-2000.- № 7.-С. 90-91.

7. Аминова Г. К., Кудаярова Р. Р., Булгаков А. К., Мазутова $A$. K. О биологической активности 1,2,4-триазинодионов-5,6 // Башкир. хим. журн.-2004.-11, № 4.-С. 15-16.

8. Костина В. Г., Лысенко Н. А., Алексеева И. В. Синтез амидов 3-[3,5-диоксо-1,2,4,5-тетрагидро-1,2,4-триазинил6]-пропанкарбоновой кислоты // Укр. хим. журн.-2003.69, № 1-2.-C. 112-119.

9. Schmidt M. W., Baldridge R. R., Boatz J. A., e.a. The general atomic and molecule electronic structure system // J. Comput. Chem.-1993.-14.-P. 1347-1363.

10. Пальчиковська Л. Г., Гарманчук Л. В., Алексєєва І. В., Усенко Л. С., Шестакова Т. С., Соляник Г. І., Швед А. Д., Чехун В. Ф. N1-глікозидні аналоги 6-азацитидину. II. Цитотоксична дія та вплив на транскрипцію in vitro // Біополімери і клітина.-2005.-21, № 5.-С. 432-438.

11. Преображенская М. Н., Мельник С. Я. Аналоги компонентов нуклеиновых кислот - ингибиторы нуклеинового обмена // Итоги науки и техники.-М.: ВИНИТИ, 1984-С. 59-70 (Биоорг. химия; Т. 1). 
12. Cozzarelli N. R., Low R. L. Mutational alteration of Bacillus subtilis DNA polymerase III to hydroxyphenylazopyrimidine resistance: polymerase III is necessary for DNA replication. // Biochem. and Biophys. Res. Communs.-1973.-51.P. 151-157.

13. Tarantino P. M., Zhi C., Gambino J. J. 6-Anilinouracil-based inhibitors of Bacillus subtilis DNA polymerase III:
Antipolymerase and antimicrobial structure-activity relationships based on substitution at uracil N3 // J. Med. Chem.-1999.-42.-P. 2035-2040.

UDC $547.872+573.3+615.28$

Received 10.04.07 